5 F. Fleischer, "Walt Whitman i svensksprgakig litteratur," Nordisk tidskrift för vetenskap, konst och industri, 38 (1962), 136.

6 Oskari Nousiainen, "Walt Whitman, Amerikan suurin runoilija" ("Walt Whitman, the greatest American poet”), Fousimies (1928), 78-80.

7 See Viljo Kajava's biographical and critical sketch of Whitman, "the first American poet," in Kirjallisuuslehti (1935), 336-342; translations of Whitman's poems, mainly from Drum-Taps, by Katri Vala and Elias Siippainen in Tulenkantajat no. 40 (1933); nos. 51-52 (1936); no. 53 (1937).

8 Viljo Kajava, "Kevät," Rakentajat (1935).

9 Arvo Turtiainen, "Itsetuholla suuruuteen," Kirjallisuuslehti 22-24 (1936).

10 Arvo Turtiainen, Tilanne 1 (1961).

11 Walt Whitman, Ruohonlehtiä (Leaves of Grass), translated by Viljo Laitinen (Turku: 1954).

12. Lauri Viljanen, “Walt Whitmania suomeksi,” Parnasso 6 (1954), 278-280.

13 Parnasso 5 (1956), 195-205.

14 Harry Järv, “Demokratins diktare," Horisont 2 (1955).

15 Niilo Peltola, The Compound Epithet in American Poetry (Helsinki: 1956).

16 Walt Whitman, Ruohoa (Leaves of Grass), translated by Arvo Turtiainen (Helsinki: 1965).

17. Hannu Launonen, "Minun puheeni ei ole ruikutusta," Uusi Suomi (January 2, 1966).

18 Harry Forsblom, "Laulu itsestään," Helsingin Sanomat (January 30, 1966).

19 Rafael Koskimies, Maailman kirjallisuus IV (Helsinki: 1965), 126-130.

20 See, for instance, Kansojen kirjallisuus 8 (1976), 504-522.

21 See Helsingin Sanomat (July 1, 1976).

\title{
MORE LIGHT ON THE EARLIEST FRENCH REVIEW OF WHITMAN
}

Since the publication of my article, "The Earliest French Review of Walt Whitman," in the Walt Whitman Quarterly Review 6 (Winter 1989), I have been referred by Roger Asselineau to information which makes clear the fact that the French translation of Leaves of Grass announced by the New York Saturday Press in 1860 was a literary hoax. That information can be found in the 1943 Harvard doctoral dissertation of Oreste Pucciani, recently published under the same title in book form, The Literary Reputation of Walt Whitman in France (New York: Garland, 1987). Basing his own claims on an article by Charles Cestre ("Un intermède de la renommée de Walt Whitman en France") published in the Revue Anglo-Américaine (13 [December 1935], 136-140), Pucciani discounts the authenticity of the proposed 1860 translation.

Had I known of those two works, my confusion regarding the mysterious circumstances surrounding the article I cited and its announcement of a forth- 
coming translation of selections from Leaves of Grass would quickly have been clarified. I would have known that the reason why I was unable to locate the original of the article or the Bibliographie Imperiale was that they were both fabrications; the reason why I was unable to trace the publishing house of Lefebvre, Martin and Co., which was announced as the issuer of the translation, was that there never was any such house; and the reason why I was unable to ascertain the identity of the supposed translator, V.H., was that he was presumably a creation of the person writing in the Saturday Press.

In short, it can be stated with certainty that there never was any plan in 1860 to bring out a French version of Leaves of Grass. The question which naturally arises, then, is why and by whom was this hoax perpetrated. Pucciani accepts the opinion of Cestre that the piece was the work of "un Français instruit des choses d'Amérique" and explains the affair as being "no more than a practical joke at Whitman's expense to regale the French-reading New Yorkers of 1860 " (p. 4). But this explanation, though plausible on the surface, ignores the context of Whitman's relations at the time with the Saturday Press and its editor-proprietor, Henry Clapp, Whitman's strongest public defender and disseminator before William Douglas O'Connor took that role upon himself. It seems to me extremely unlikely that Clapp, whose own remarks, written in the name of the Press, appeared before and after the reprinted French article, would have allowed his weekly to be used to deprecate his friend Whitman or that he himself would have joined in a game of Whitman mockery. Just several months before, he was dependent, as I have argued, on Whitman's good will in seeking capital from the publishers of the 1860 Leaves for his struggling weekly; and in any case there is no known evidence to support the idea that he and Whitman were on anything but excellent terms throughout that year.

This is not to say that Clapp was uninvolved in the hoax; nothing that appeared in the Saturday Press appeared without his knowledge. In fact, the most likely explanation of the affair is that Clapp himself actively took part in, perhaps even perpetrated, the whole affair. Playing on the gullibility of the public would have been a trait entirely consonant with Clapp's personality, although his motivation in doing so would surely have been to perform an act to Whitman's benefit rather than at his expense. Since he had been doing his best all that summer and autumn to spread the reputation of Whitman and Leaves of Grass, it is reasonable to see this supposed internationalization of Whitman as one more ploy in his ongoing strategy of bringing Whitman's poetry to the attention of the general reading public. In order to advance this goal, Clapp, a well-known Francophile who was said to speak and write French like a native, either recruited an acquaintance or, quite possibly, took it upon himself to write the text of the article and to translate the selections from Leaves that appeared with the article as excerpts from the forthcoming translation. In fact, although attributing the authorship of the piece to anyone must remain a matter of speculation, the impishness of the article and the verbal gamesmanship of the translations strongly suggest to me the personality and manner of Henry Clapp. 